\title{
U.S. Department of the Interior Causes of Variations in Water Quality and Aquatic U.S. Geological Survey Ecology in Rivers of the Upper Mississippi River Basin, Minnesota and Wisconsin
}

\section{Introduction}

Physical and aquatic biological conditions differ among the Mississippi River and its major tributaries (the St. Croix and Minnesota Rivers) in Minnesota and Wisconsin. The quality of surface water and the ecological condition of rivers affect the ways in which we use them. The St. Croix River is used for recreation; the Mississippi River is used for recreation and is a corridor for commerce; and the Minnesota River primarily drains agricultural lands. Analysis of the environmental framework of the basins and water-quality and ecological information by the National Water-Quality Assessment (NAWQA) Program shows that the conditions of the rivers are a product of a combination of factors including climate, hydrology, geology, soils, land use, land cover, water management, and water use.

\section{Environmental Framework}

The Upper Mississippi River Basin study unit (fig. 1) includes the Mississippi River Basin from its source at Lake Itasca to Lake Pepin, and the basins of the Minnesota and St. Croix Rivers. Natural and human factors (including climate, hydrology, geology, soils, land use, land cover, water management, and water use) affect water quality and aquatic ecology in rivers and streams in the Upper Mississippi River Basin.

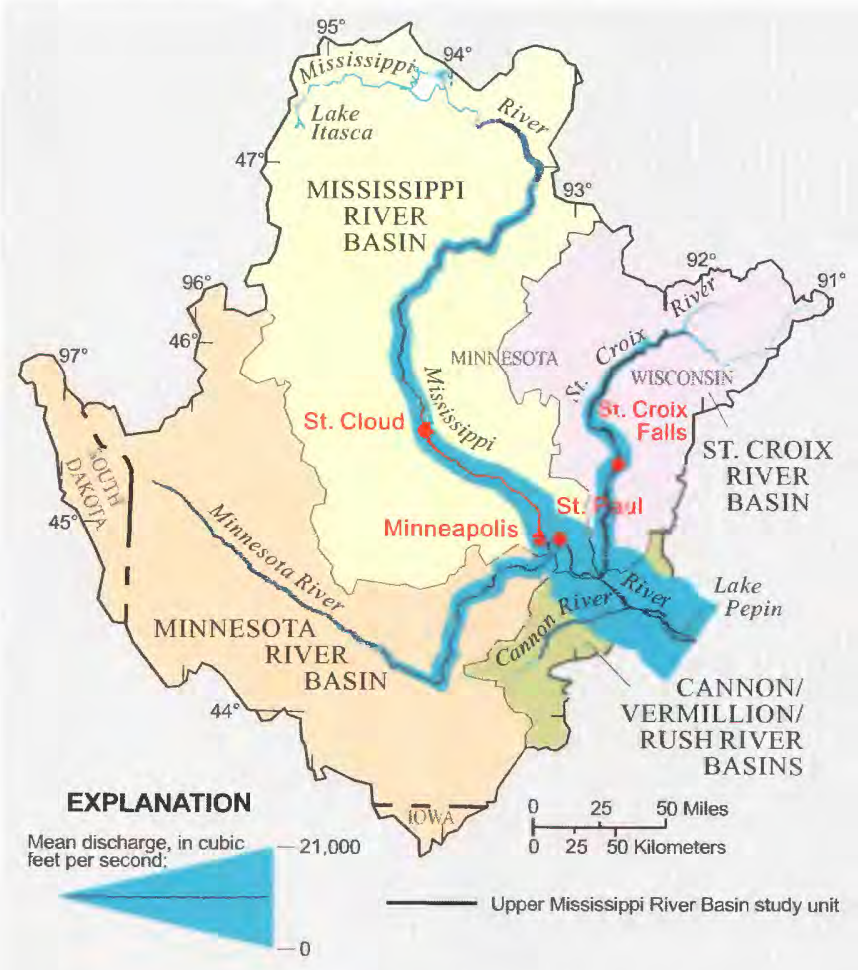

Figure 1.--Location of the Upper Mississippi River Basin study unit, major river basins and streamflow of major rivers in the study unit.

\section{Natural Factors}

Differences in climate across the 47,000 square mile basin affect hydrology. Average annual precipitation ranges from 22 inches in the west to 32 inches in the east. Mean annual evapora- tion (annual free-water surface evaporation) ranges from less than 28 inches in the northeast to more than 40 inches in the southwest. Normal annual temperatures (1961-90) range from 44 degrees Fahrenheit in the south to 38 degrees Fahrenheit in the north.

Mean annual runoff, which is related to precipitation and evapotranspiration, increases from west to east. Runoff ranges from less than 2 inches in the headwaters of Minnesota River to more than 14 inches in the upper St. Croix River Basin. The headwaters of the St. Croix River yield the most runoff because precipitation is greater than potential evapotranspiration.

Streamflow is generally greatest in spring and early summer as a result of melting snow, rains falling on melting snow, or heavy rains falling on saturated or frozen soils. Streamflow varies least during winter, when ground-water inflow to streams is dominant and varies most during late summer and fall, when locally heavy rains and thunderstorms occur. Differences in precipitation, evaporation, and drainage areas lead to different discharges in major rivers. The average flow of the Mississippi River (fig. 1), just upstream of the Twin Cities, is $7,900 \mathrm{ft}^{3} / \mathrm{s}$ (cubic feet per second) based on data from 1935-93. Average flow of the Minnesota River near its mouth is $4,060 \mathrm{ft}^{3} / \mathrm{s}$ and the average flow of the St. Croix River at St. Croix Falls, Wisconsin is $4,770 \mathrm{ft}^{3} / \mathrm{s}$ (fig. 1) based on data from 1931-92.

The Mississippi River flows southward through glacial moraines and outwash plains. Surficial geology in the basin affects the characteristics of streamflow and chemical quality of water in the rivers. In the northeast, siliceous, sandy sediments were deposited by glaciers which traversed igneous and metamorphic rocks. The remainder of the basin is mantled by more clay-rich, calcareous glacial sediments from glaciers which traversed calcareous rocks, sandstone, and shales (Ruhl, 1987).

\section{Human Factors}

Population density and land use can also affect hydrology, water quality, and aquatic ecology. The greatest effects occur in areas with the highest population densities or where disruption of natural land cover is substantial. The population of the basin in 1990 was about $3,640,000$. Seventy-five percent of those people reside in the Twin Cities metropolitan area, which is located near the confluence of the Mississippi, Minnesota, and St. Croix 
Rivers, and which comprises nearly 80 percent of all urban land in the study unit (fig. 2).

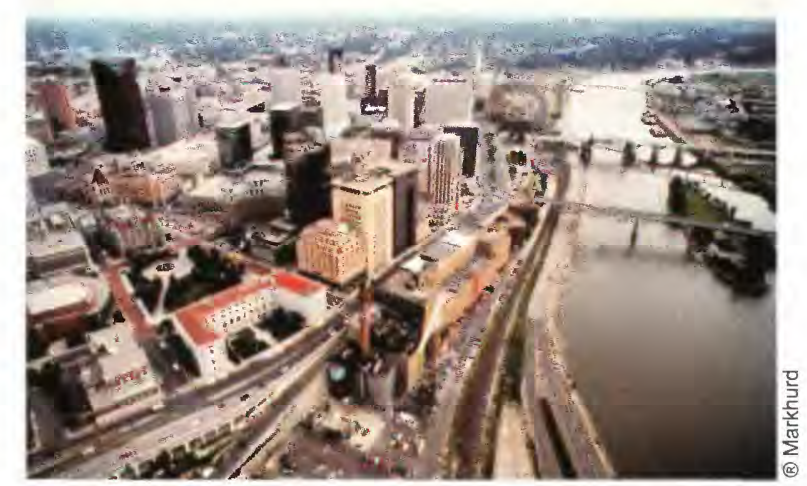

Figure 2.--Aerial view of St. Paul, Minnesota on the banks of the Mississippi River.

Land cover (fig. 3) in the basin can be categorized by three zones: an agricultural zone across the southwestern one-third of the basin (fig. 4); a forested zone across the northeastern onethird; and a transitional zone between these areas. About 63 percent of the study unit is agricultural and range land (cropland, pasture). The remaining land use and land cover consists of forests (about 22 percent), water and wetlands (about 13 percent), urban land (about 2 percent), and other categories (less than 1 percent).

Our use of water and the ways in which we dispose of wastewater also can affect the quality and discharge of rivers. An average of 413 million gallons of water per day is used in the basins -59 percent from ground-water and 41 percent from surface water. This total is equal to about one-tenth of the average flow of the Mississippi River upstream of the Twin Cities. Ultimately, most water used is returned to the rivers as wastewater, which is treated before being discharged. The Metropolitan Wastewater Treatment Plant downstream from St. Paul is the largest point source discharge to the Mississippi River within the study unit, discharging 225 million gallons per day (L.C. Dyste, Metropolitan Council Environmental Services, oral commun., 1996).

\section{Surface-Water Quality and Aquatic Ecology}

The quality of water and the ecology of rivers in the basin are affected by a combination of physical, ecological and human factors. Alkalinity and dissolved-solids concentrations in streams are controlled by the composition of rocks and soils and generally increase across the basin from the northeast to the south. Alkalinities range from less than $50 \mathrm{mg} / \mathrm{L}$ (milligrams per liter) in the upper St. Croix River to greater than $400 \mathrm{mg} / \mathrm{L}$ in the Minnesota River (fig. 5). Lower alkalinities in the upper St. Croix River are due to drainage from basins with relatively insoluble siliceous soils and geologic deposits. In the Minnesota River Basin, drainage from basins with soils and geologic materials rich in carbonates and shales increase alkalinities in drainage water. In the Mississippi River alkalinity generally increases in a downstream direction. Below the confluence of the Minnesota and Mississippi Rivers, greater alkalinities and dissolvedsolids concentrations are due to water from the Minnesota River.

Suspended sediment adversely affects aquatic life and transports nutrients, trace elements, and organic pollutants sorbed to

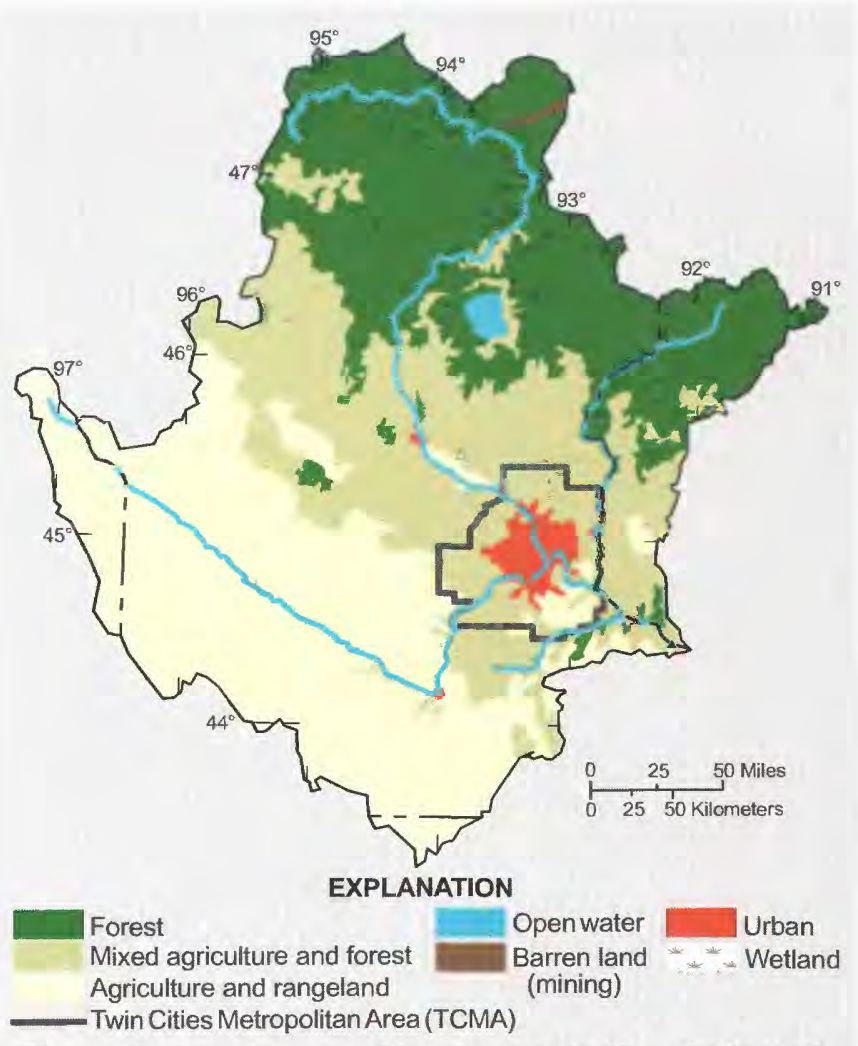

Figure 3.--Land use and land cover in the study unit.

particle surfaces. Sediment delivery to streams is accelerated by land-cover disturbances by agriculture, construction, aggregate mining, forestry, and stream-bank and bed erosion. Sediment concentrations in rivers generally increase toward the south across the basin (fig. 5). Suspended-sediment concentrations are greatest in the Minnesota River because of soil conditions and agricultural activities in the basin. Suspended-sediment distributions in the Mississippi River are affected by locks and dams and input from the Minnesota River. Suspended-sediment concentrations in the Mississippi River increase below its confluence with the Minnesota River and decrease downstream due to sediments settling out in navigation pools upstream from dams, and due to dilution from the St. Croix River.

Nutrients (nitrogen and phosphorus compounds) in water contribute to eutrophication of rivers and lakes. Eutrophication, the accelerated growth of algae and aquatic vegetation, can cause significant changes in concentrations of dissolved oxygen in water, including supersaturation and oxygen depletion during the summer. Sources of nutrients in rivers include fertilizers, animal wastes, wastewater effluent, faulty septic systems, combined sewer overflow, and atmospheric deposition. Nitrate $\left(\mathrm{NO}_{3}{ }^{-}\right)$concentrations in the Minnesota River periodically exceed state and Federal drinking water standards ( $10 \mathrm{mg} / \mathrm{L}$ as nitrogen $)$ during spring runoff (fig. 5). A study of the lower 40 miles of the Minnesota River by the Metropolitan Waste Control Commission (1994a) determined that nitrate concentrations were greatest in the tributaries draining watersheds with extensive drain-tile networks. Nitrate concentrations also were elevated in the Mississippi River downstream of the Twin Cities, primarily due to inflows from the Minnesota River. Nitrate concentrations are less in the St. Croix River and in the Mississippi River above St.Cloud, both of which drain predominantly forested areas (fig. 6). 


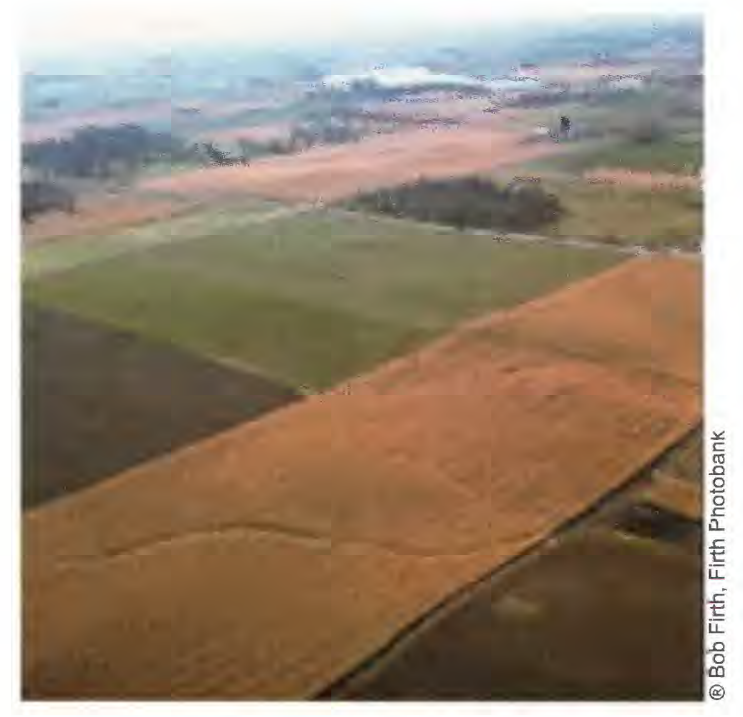

\section{Figure 4.--Aerial view of crop land in the Minnesota River Basin.}

Nitrogen and phosphorus are both abundant in the Mississippi River below the confluence with the Minnesota River. Low-flow conditions support the growth of algae, especially in pooled areas. This occurred in the summer of 1988, a drought year, when severe nuisance algal blooms occurred in Lake Pepin, a natural lake on the Mississippi River (Minnesota Pollution Control Agency, 1989).

Dissolved oxygen is necessary for the survival of most aquatic life forms. Dissolved-oxygen concentrations are influenced by plant growth, the decay of organic matter in streams, reaeration, and water temperature. Dissolved-oxygen concentrations generally exceed the minimum $5 \mathrm{mg} / \mathrm{L}$ water-quality criterion (U.S. Environmental Protection Agency, 1986) for the protection of aquatic life. Low dissolved-oxygen concentrations, related to blue-green algal blooms, caused fish kills in Lake Pepin during the summer of 1988 drought (Minnesota Pollution Control Agency, 1989). In the Twin Cities metropolitan area, point and nonpoint sources of oxygen-demanding substances reduce aquatic oxygen concentrations and have, in the past, caused violations of the dissolved-oxygen criterion in the Mississippi and Minnesota Rivers, primarily below wastewatertreatment-plant outfalls. However, recent improvements in wastewater treatment have resulted in improved water quality below those outfalls.

Land-use activities in the basin also have contributed to elevated counts of bacteria and elevated concentrations of trace metals in streams. Fecal coliform bacteria indicate the presence of animal and human wastes in water and the potential for disease-causing organisms. Fecal bacteria counts are greatest in the Minnesota River and in the Mississippi River as it flows through the Twin Cities. Payne (1994) showed that approximately 40 percent of samples collected in the Minnesota River Basin exceeded the 200 colonies $/ 100 \mathrm{~mL}$ ambient water-quality criterion (U.S. Environmental Protection Agency, 1986). Data collected by the Metropolitan Waste Control Commission (1994b) show the water-quality criterion for bacteria was sometimes exceeded in the Mississippi River just downstream of the Minnesota River and downstream of the Metropolitan Wastewater Treatment Plant.
Elevated concentrations of many trace metals are toxic to aquatic organisms and to humans. Human activities can have a strong influence on the presence of many trace elements in both stream water and sediment. Industries use large quantities of many elements that would otherwise not be present in natural waters. Recent wastewater treatment efforts have reduced the total amount of trace metals discharged to the Mississippi River. In the Twin Cities metropolitan area, concentrations of most trace metals, with the periodic exception of mercury and copper, are generally below state or Federal ambient and drinking-water quality standards (Metropolitan Waste Control Commission, 1994a). Concentrations of iron and manganese in the St. Croix River Basin, probably associated with natural sources, sometimes exceed the Secondary Maximum Contaminant Levels (SMCL's) set by the U.S. Environmental Protection Agency for drinking water of $300 \mu / \mathrm{L}$ (micrograms per liter) and $50 \mu / \mathrm{L}$, respectively (U.S. Environmental Protection Agency, 1988). Concentrations of cadmium, lead, and mercury are generally greatest in bed sediment samples immediately downstream from the Twin Cities metropolitan area (Wiener and others, 1984).

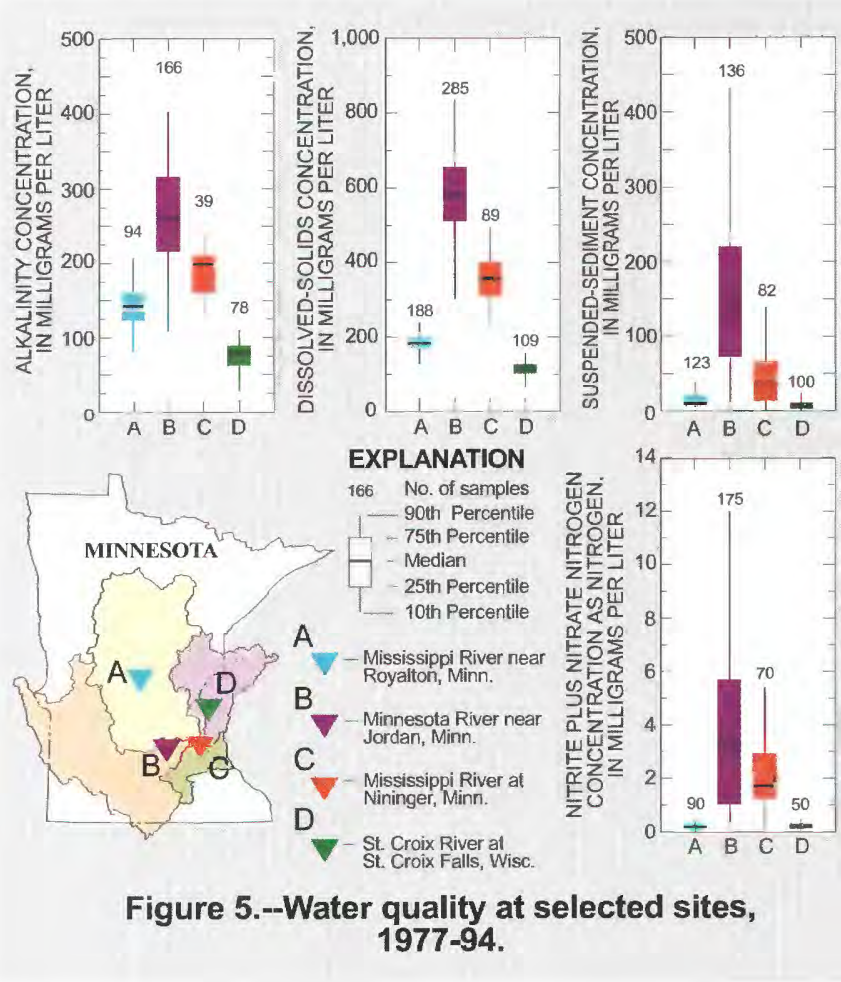

Biological communities and ecological conditions are affected by chemical and physical conditions in rivers. Changes in the physical aquatic habitat in rivers in the basin are caused by construction of the locks and dams and changes in land use. Construction and maintenance of locks and dams has altered physical habitat for fish and invertebrate fauna on the Mississippi River by changing stream flow from free-flowing to impoundment-like conditions and by periodic dredging to maintain the navigation channel. Drainage of wetlands, loss of riparian vegetation and channel straightening in the Minnesota River Basin have reduced habitat, modified hydraulic conditions, and may have changed water quality.

Fish found in rivers in the basin include both warm- and cool-water species because of variability in the temperature of 


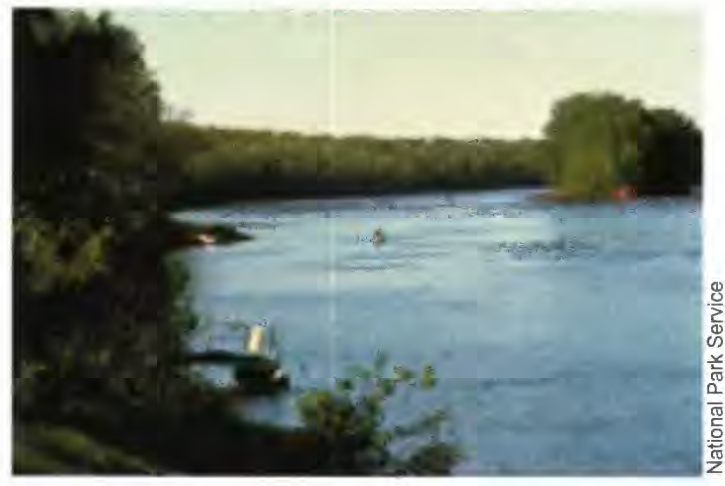

Figure 6.--Canoeist on the St. Croix River.

water in rivers throughout the basin. On the Mississippi River, a dam at Coon Rapids and St. Anthony Falls at Minneapolis and St. Croix Falls on the St. Croix River physically separate the fish fauna of each of the rivers. There are approximately 70 species of fish in the Mississippi River above St. Anthony Falls and about 120 species below the falls. In the St. Croix River, there are about 75 species above St. Croix Falls and about 90 species below. The Minnesota River Basin has 84 native species of fish. Several species of mollusks have been lost due to commercial exploitation, loss and modification of habitat, water pollution, siltation, and introduction of exotic mussel species (Zebra mussels) (Mueller, 1993). There are two Federally-listed endangered mollusk species in the lower St. Croix and Mississippi Riversthe Higgin's Eye (Lampsilis higginsi) mussel and the Winged Mapleleaf (Quadrala fragosa) mussel.

\section{Summary and Conclusion}

Water quality in the main tributaries in the Upper Mississippi River in Minnesota and Wisconsin is generally suitable for most uses. The water quality and ecological condition of the Upper Mississippi River and its major tributaries (the St. Croix and the Minnesota Rivers) differ and are related to natural and human factors. Natural differences among the major tributaries have always been reflected in differences in water quality and ecological conditions of rivers in the basin. Uses of the land and rivers and patterns of population density also are related to natural conditions in each of the major tributary basins. Our use of the land has accentuated natural differences in water quality and ecological conditions in each of the three major rivers in the Upper Mississippi River Basin.

\section{References Cited}

Metropolitan Waste Control Commission, 1994a, Water quality analysis of the Lower Minnesota River and selected tributaries-River (1976-1991) and non-point source (19891992) monitoring, volume $1,142 \mathrm{p}$.

— 1994b, 1992 Water quality summary report, $52 \mathrm{p}$.

Minnesota Pollution Control Agency, 1989, Review of water quality conditions in Lake Pepin for the summer of 1988, $51 \mathrm{p}$.

Mueller, L., 1993, Winged Mapleleaf mussel and Higgin's Eye pearly mussel-Freshwater mussels threatened with extinction: Minnesota Department of Agriculture, St. Paul, Minnesota, $19 \mathrm{p}$.

Payne, G. A., 1994, Sources and transport of sediment, nutrients, and oxygen-demanding substances in the Minnesota River Basin, 1989-92: U.S. Geological Survey Water-Resources
Investigations Report 93-4232, $71 \mathrm{p}$.

Ruhl, J.F., 1987, Hydrogeologic and water-quality characteristics of glacial-drift aquifers in Minnesota: U.S. Geological Survey Water-Resources Investigations Report 87-4224, 2 plates.

Stark, J.R., Andrews, W.J., Fallon, J.D., Fong, A.L., Goldstein, R.M., Hanson, P.E., Kroening, S.E., and Lee, K.E., 1996, Water-quality assessment of part of the Upper Mississippi River Basin, Minnesota and Wisconsin-Environmental setting and study design: U.S. Geological Survey WaterResources Investigations Report 96-4098, 62 p.

U.S. Environmental Protection Agency, 1986, Quality criteria for water, 1986: U.S. Environmental Protection Agency, EPA 801-F-94-001A, 4 p.

1988, Secondary maximum contaminant levels (Section 143.3 of Part 143, National Secondary Drinking-Water Regulations), U.S. Code of Federal Regulations, title 40, parts 100 to 149, revised as of July 1, 1988, p. 608.

Wiener, J.G., Jackson, G.A., May, T.W., and Cole, B.P., 1984, Longitudinal distribution of trace elements (As, $\mathrm{Cd}, \mathrm{Cr}, \mathrm{Hg}$, $\mathrm{Pb}$, and $\mathrm{Se}$ ) in fishes and sediments in the Upper Mississippi River, in Wiener, J.G., Anderson, R.V., McConville, D.R., eds., Contaminants in the Upper Mississippi River, Butterworth Publishers, Boston, Mass., p. 139-170

In 1991, the U.S. Geological Survey (USGS) began to implement the NAWQA Program. Goals of NAWQA are to (1) describe water-quality in a large part of the Nations freshwater streams, rivers, and aquifers; (2) describe how water quality changes over time and; (3) improve the understanding of how physical, ecological, and human factors that affect water-quality. The Upper Mississippi River Basin was selected as one of 60 NAWQA study units because it represents a major hydrologic region with important natural waterquality implications. Water quality of the Mississippi River, the largest river in the Nation, is of concern because it is a major transportation route and source of potable water. Factors that affect water quality, such as geomorphology, climate, hydrology, land use, and land cover, are being studied relative to specific water-quality issues that affect the river basin (Stark, 1996). Existing data from Federal and State agencies including the Metropolitan Council Environmental Services, the Minnesota Department of Agriculture, the Minnesota Department of Health, the Minnesota Department of Natural Resources, the Minnesota Pollution Control Agency, and the Wisconsin Department of Natural Resources were reviewed to aid in the design of the data-collection network. Information from the analysis is being used to identify sites where additional sampling is needed to provide the scientific information needed to manage and sustain the quality of their rivers in the future.

Prepared by James R. Stark

For more information, contact:

Upper Mississippi River Basin NAWQA Coordinator U.S. Geological Survey 2280 Woodale Drive

Mounds View, Minnesota 55112

Phone (612) 783-3100

http://wwwmn.cr.usgs.gov/umis 